$1-1-1987$

\title{
Economic feasibility of cogeneration at sawmills in West Virginia
}

\author{
Samuel M. Brock \\ David Walter Patterson \\ Joshua O. Ruan
}

Follow this and additional works at: https://researchrepository.wvu.edu/ wv_agricultural_and_forestry_experiment_station_bulletins

\section{Digital Commons Citation}

Brock, Samuel M.; Patterson, David Walter; and Ruan, Joshua O., "Economic feasibility of cogeneration at sawmills in West Virginia" (1987). West Virginia Agricultural and Forestry Experiment Station Bulletins. 697.

https://researchrepository.wvu.edu/wv_agricultural_and_forestry_experiment_station_bulletins/591 @ WVU. It has been accepted for inclusion in West Virginia Agricultural and Forestry Experiment Station Bulletins by an authorized administrator of The Research Repository @ WVU. For more information, please contact ian.harmon@mail.wvu.edu. 


\section{Economic Feasibility of Cogeneration at Sawmills in West Virginia}

Bulletin 697

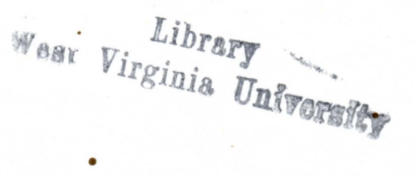

July 1987 :

Agricultural and Forestry Experiment Station

West Virginia University
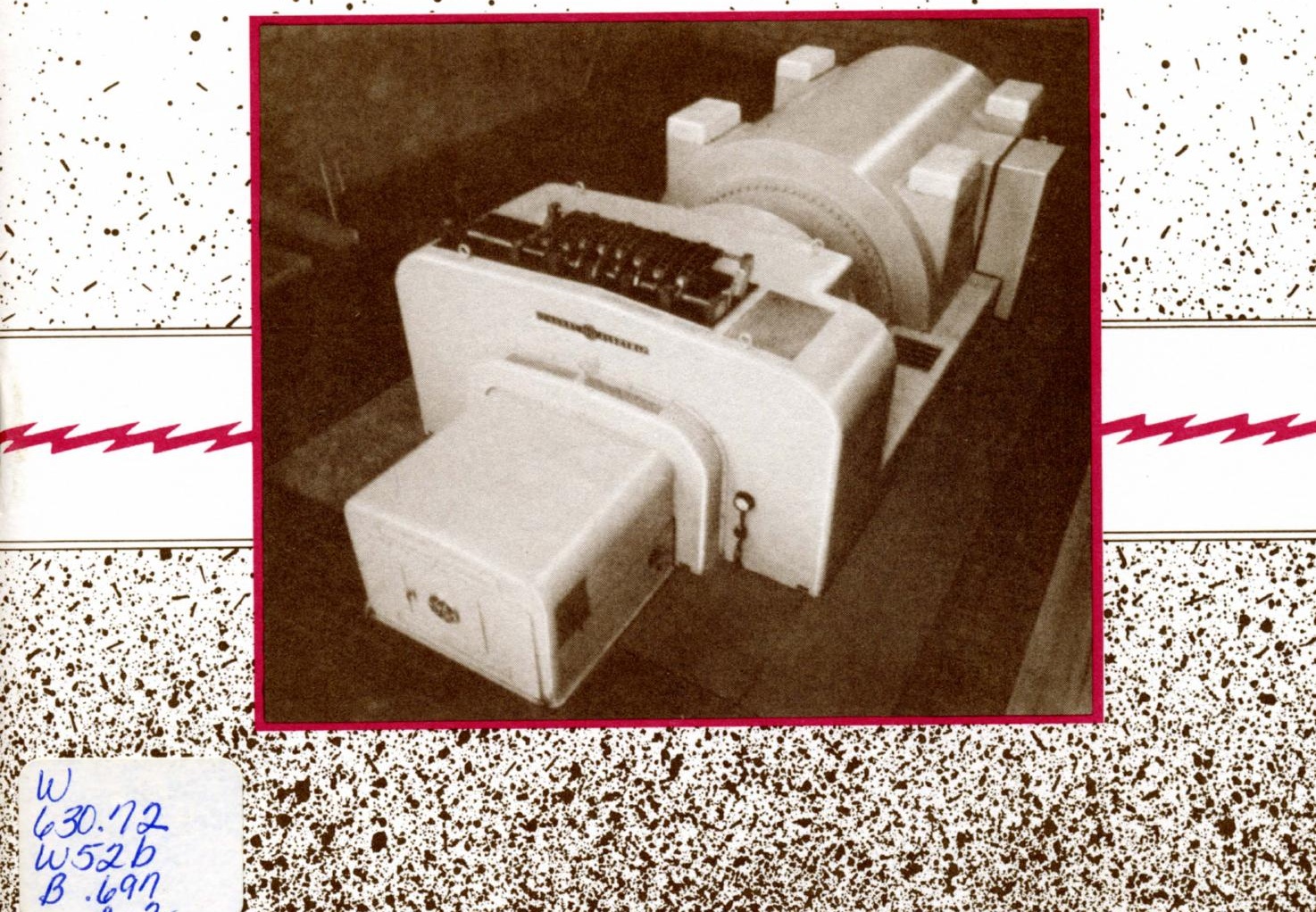


\title{
Authors
}

Samuel M. Brock is forest scientist, David W. Patterson is assistant wood scientist, and Joshua $\mathrm{O}$. Ruan at the time of this study was graduate research assistant in the Division of Forestry, West Virginia Agricultural and Forestry Experiment Station, West Virginia University.

The research reported herein was conducted under the auspices of the West Virginia Agricultural and Forestry Experiment Station at West Virginia University. Major financial support was provided by the Tennessee Valley Authority's Southeastern Regional Biomass Energy Program under Contract No. TV-65623A.

\author{
West Virginia University \\ Agricultural and Forestry Experiment Station \\ College of Agriculture and Forestry \\ Robert H. Maxwell, Director \\ Morgantown
}

Final report to the Tennessee Valley Authority's Southeastern Regional Biomass Energy Program on Contract No. TV-65623A. 


\section{Contents}

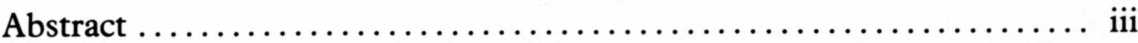

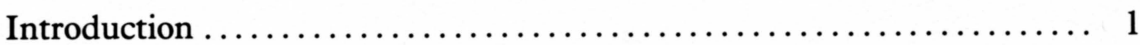

Objectives $\ldots \ldots \ldots \ldots \ldots \ldots \ldots \ldots \ldots \ldots \ldots \ldots \ldots \ldots \ldots \ldots \ldots \ldots \ldots \ldots \ldots \ldots, 2$

Studies on the Economics of Kiln Drying ..................... 2

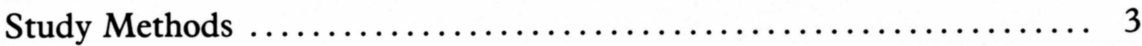

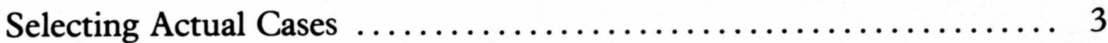

Defining Hypothetical Cases ............................ 4

Using Multipliers to Estimate Investment $\ldots \ldots \ldots \ldots \ldots \ldots \ldots \ldots \ldots$

Constructing the Cash Flow Table $\ldots \ldots \ldots \ldots \ldots \ldots \ldots \ldots \ldots \ldots \ldots$

Electricity savings (actual firms) $\ldots \ldots \ldots \ldots \ldots \ldots \ldots \ldots \ldots \ldots \ldots$

Electricity savings (hypothetical firms) $\ldots \ldots \ldots \ldots \ldots \ldots \ldots \ldots \ldots \ldots$

Incremental fuel cost ............................... 8

Other incremental operating and maintenance costs $\ldots \ldots \ldots \ldots \ldots 10$

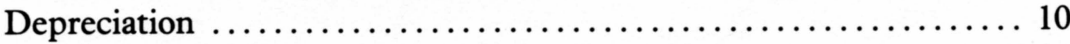

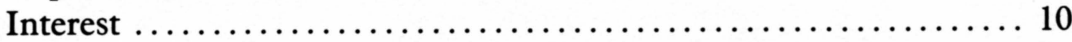

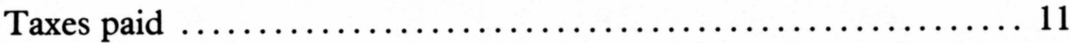

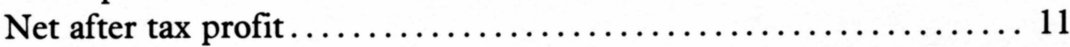

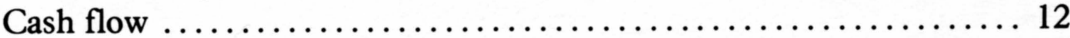

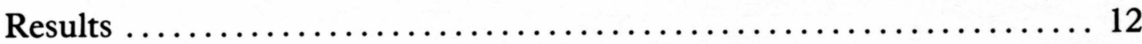

Actual Cases ...................................... 12

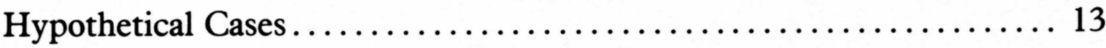

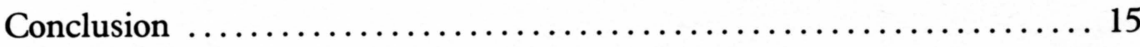


[Blank Page in Original Bulletin] 


\section{Abstract}

This study was undertaken to evaluate the economic feasibility of cogeneration at sawmills in West Virginia, using wood residue for boiler fuel. In making the study, it was assumed that certain types of conventional kiln drying were highly profitable, and that the initial step in making a cogeneration investment was to decide whether or not to invest in equipment to produce process steam for a dry kiln. Once this decision has been made, it can be decided if an incremental investment in a complete cogenerating system is economically desirable. This study is concerned only with incremental cash flows.

At the time cash flow calculations were made, it was uncertain whether tax reform legislation then before Congress would contain provisions for investment or energy tax credits. It was decided to provide a basis for comparing the 1985 situation with the worst future situation envisioned, where no tax credits would be permitted.

To avoid disclosure, the actual companies studied were designated Firms A, $B$, and $C$. The total capital investment in the cogenerating system ranged from $\$ 2,113,650$ for Firm B to $\$ 358,050$ for Firm C. The latter figure represented investment entirely in used equipment. For Firm A, NPV calculations were acceptable both when it was assumed tax credits could be taken and when they could not. Firm A was making an attractive profit on its cogeneration. For Firm $\mathrm{B}$, however, the NPV was acceptable when tax credits could be taken and unacceptable otherwise. NPV's for Firm C were acceptable for both alternatives.

Hypothetical cases were defined for four sawmill size classes: 15, 10, 5, and 1, all in millions of board feet annually. An investment ranging from $\$ 2,017,785$ for the largest sawmill size to $\$ 643,681$ for the smallest was required for the cogenerating system. For sawmills cogenerating 24 hours per day for 360 days per year, assuming tax credits could be taken and avoided costs were $\$ 0.035$ per kwh, the NPV figures were economically acceptable for all but the smallest size class mill. When no tax credits were permitted, and avoided costs were held at the $\$ 0.035$ per kwh level, only the 15 and 10 million board feet-size classes were economically feasible. When no tax credits were allowed, and avoided costs were reduced to $\$ 0.0175$, all four size classes were economically infeasible.

Cogenerating for only 10 hours per day for 250 days per year mainly to meet the plants' own needs for electricity does not appear to be as productive as cogenerating for longer periods and selling the excess electricity. Assuming tax credits were permitted and avoided costs were $\$ 0.035$ per $\mathrm{kwh}$, hypothetical firms cogenerating only 10 hours per day produced economically acceptable NPV's only for the two largest size class sawmills. When no tax credits were permitted, with avoided costs at the $\$ 0.035$ per kwh level, only the largest size class sawmill was feasible. This same size class was feasible with no tax credits and avoided costs at $\$ 0.0175$ per kwh. 
There appear to be substantial economies to scale associated with cogeneration at sawmills. This process is decidedly more attractive to those firms producing 10 million and more board feet annually. Furthermore, these larger sawmills are in a stronger position to attract the financing investments that cogeneration requires. Experience gained at such large installations will determine whether cogeneration at sawmills will play an important role in the future development of the lumber industry. 


\section{Economic Feasibility of Cogeneration at Sawmills in West Virginia}

Samuel M. Brock, David W. Patterson and Joshua O. Ruan

\section{Introduction}

Production costs have been rising in the lumber industry for many years. Revenues have not always increased at concommitant rates. Many sawmill operators, caught in this cost-revenue squeeze, have been forced out of business. Lumber prices have been increasing owing to the cost increase. Consequently, the industry has been producing less abundantly at a higher cost rather than more abundantly at a lower cost (Duerr 1960). This is symptomatic of a declining industry.

Under the circumstances it behooves those interested in the economic health of the lumber industry to look for ways to reduce costs or increase revenues. Investments in conventional steam-heated dry kilns with wood residue-fired boilers and steam electric generators may help to improve the profitability of lumber making. Kiln drying produces a higher value product which yields an attractive return on invested capital. Using some of the process steam to operate a generator can make a sawmill energy self-sufficient while producing some electricity for sale, a direct boost to revenues. Information on the economic feasibility of generating electricity through a cogenerative process for sawmills in West Virginia will be compiled in this research. In doing so it will be assumed that certain systems of conventional kiln drying are highly profitable, and that the initial step in making a cogeneration investment is to decide whether or not to invest in equipment to produce process steam for a dry kiln. Once this decision has been made, it can be decided if the additional investment in a larger boiler (when appropriate), a generator, and associated electrical hardware is economically desirable.

There is a strong economic incentive for sawmill operators to utilize wood residue for fuel in an attempt to become more energy self-sufficient. Prices of competing fuels such as oil and natural gas have increased rapidly since the oil crisis of 1973. Currently, wood is one of the cheapest fuels available. At a price of $\$ 12$ per ton, dry wood residue costs only $\$ 1.12$ per million Btu. On the other hand, at a price of $\$ 0.90$ per gallon, oil costs $\$ 7.50$ per million Btu. And natural gas priced at $\$ 0.45$ per Therm costs $\$ 5.63$ per million Btu. So utilization of wood residue provides the sawmill operator with a very favorable opportunity to substitute relatively inexpensive energy for higher priced fuel. 


\section{Objectives}

The main objective of this study was to develop a computer program for evaluating investment opportunities in cogeneration at sawmills and to use it to calculate net present value (NPV) for three actual cases and several hypothetical ones. The latter were designed to span the range in size of sawmills in West Virginia. These computations, and associated information, should be useful to sawmill operators, government officials, and extension personnel in evaluating the economic feasibility of cogeneration.

\section{Studies on the Economics of Kiln Drying}

Metz (1985) recently completed a comprehensive study of the economics of lumber drying at a central location in West Virginia. Enterprises evaluated included kiln drying green lumber, kiln drying air-dried lumber, and kiln drying lumber that had been partially dried in a low-temperature pre-drier. A conventional steam-heated kiln with a wood residue-fired boiler was used in these drying applications.

Metz (1985) used NPV as a criteria for evaluating each system. A discount rate of 15 percent was used in this analysis, and a ten-year period was adopted for making projections. The conventional steam-heated kiln loading green lumber produced a NPV of minus $\$ 193,475$, which obviously would not be acceptable. Loading air-dried lumber into the kiln was profitable, however. This system showed a NPV of $\$ 3,387$. Thus, it would generate a return of over 15 percent on invested capital with an annual output of 5.4 million board feet.

The most profitable investment was the steam-heated kiln loaded with pre-dried lumber. This system required less land and far less inventory than did the system using air-dried lumber. The NPV was $\$ 1,202,107$. The annual volume was 5.4 million board feet, as was the case with the air-dried system. The pre-dried lumber system was by far the most attractive of the three conventional kiln alternatives considered (Metz 1985).

A 1981 study on the economics of lumber drying by Fields and Duncan produced similar results. In this study, made for East Kentucky, loading green lumber into a conventional kiln heated with a wood residue-fired boiler was not financially attractive. On the other hand, a conventional kiln loading air-dried lumber yielded a return on investment (ROI) of 17.5 percent. But by investing in a fan pre-drier and reducing the investment in land and plant proportionately, a slightly larger overall investment can yield up to 33.4 percent ROI. This higher ROI results from the high production level achieved when lumber enters the kiln at a consistent 20 percent moisture content from the pre-drier instead of an average 25 percent when air-dried (Fields and Duncan 1981).

Thus, two independent studies have shown loading of air-dried and predried lumber into a conventional steam-heated kiln with wood residue-fired 
boiler would yield a profitable product. It is assumed that such enterprises would be similarly profitable for the cases studied in the present research.

In 1985, Walton developed an interactive computer program, written in Basic, designed to determine the economic feasibility of installing conventional steam-heated dry kilns and a wood residue-fired boiler. This program is similar in some respects to the one developed here, and is available through the West Virginia University Division of Forestry.

\section{Study Methods}

\section{Selecting Actual Cases}

There were no cogenerating sawmills operating in West Virginia during 1985. There was one sawmill so equipped but it did not operate. So all three actual cases studied in this project were located in neighboring states.

The first case studied was located in Pennsylvania, about a two-hour drive from the West Virginia University campus in Morgantown. This was the only sawmill in Pennsylvania using steam to generate electricity. Virginia had two sawmills operating steam electric generators, but one of these was experiencing significant difficulties and, having limited regular operating data, was not studied. The third and last case studied was the only cogenerating sawmill in Kentucky.

The actual case study firms cooperating in this study were not identified owing to the confidential and revealing nature of the information they supplied about their operations. In presenting the results, only limited descriptive information was provided so that these firms may not be easily identified, and the state in which a particular firm was located was not indicated. For purposes of this report, these sawmills will be designated Firms A, B, and C, not necessarily in the order given above.

Cogeneration at sawmills producing steam heat for dry kilns and electricity from the same energy source, occurs very infrequently in West Virginia and neighboring states. The reasons for this should become more apparent as the results of this research are related.

Special forms were used to collect data on purchased equipment costs from the sawmill owner or manager. Unfortunately, the respondents usually could not provide information on installation costs, other plant construction costs including instrumentation and controls, piping, buildings, and indirect costs. Data required to calculate the difference in fuel costs with and without cogeneration (incremental fuel costs) were available and obtained, as was information necessary to compute the incremental electricity savings. The latter represent the revenues earned by generating electricity, both for the firm's own use and for sale to an electric utility. The last category of data collected was other operating and maintenance costs, which included operating 
labor, annual routine maintenance, costs for water and chemicals for water treatment, and insurance. The base case (without cogeneration) operating and maintenance costs also were determined.

\section{Defining Hypothetical Cases}

The hypothetical cases, all assumed to operate in West Virginia, were for four sawmill size classes. These were sawmills with annual production of 15 million board feet, 10 million board feet, 5 million board feet, and 1 million board feet. Two scenarios were envisioned for each of these four sawmill sizes. Under one, the sawmill would cogenerate for 24 hours per day for 360 days per year, with five days down time for annual maintenance. Under the other, the sawmill would cogenerate for 10 hours per day for 250 days per year. In the first instance the firm would produce excess electricity for sale while meeting all of its own needs for power. In the second one, a small amount of electricity would be available for sale but the main objective would be to satisfy the firm's own needs for power.

For the hypothetical cases, information on the purchase price of equipment was supplied by manufacturers, as were data on fuel use and maintenance costs. Some equipment manufacturers also provided estimates of installation costs, but none was able to supply other cost items needed such as outlays for piping, buildings, indirect costs, and the like.

Cost data for new 250 psig wood-burning boilers complete with fuel storage and handling equipment were obtained from R. W. Gorman Associates of Washburn, Wisconsin. This firm also supplied information on fuel use. These data were procured for each sawmill size class. Data on steam turbine generator purchase costs were supplied by Terry Corporation of Windsor, Connecticut. Information on the cost of major electrical gear was obtained from O'Brien Machinery Company of Downingtown, Pennsylvania. These cost estimates were verified for accuracy by comparing them with figures obtained from a few other companies for each sawmill size class.

\section{Using Multipliers to Estimate Investment}

It was relatively easy to obtain purchase prices for all of the equipment used in cogeneration for both the actual cases and for the hypothetical ones. However, it was not possible to obtain detailed information on other construction and indirect costs. These costs are needed to compute fixed capital investment, a figure required for economic analysis of the cogeneration enterprise. Fortunately, using a well-established engineering technique, these latter unknown costs could be estimated.

This technique recognizes that the cost of a plant may be obtained by multiplying the basic equipment cost by some factor to approximate capital investment. The percentages given in Table 1 were used in this study to 
estimate fixed capital investment based on delivered equipment cost. They were taken from Peters and Timmerhaus (1980) and modified for application in this research. Total purchased equipment costs were multiplied by the factor 2.31 to estimate fixed capital investment for all cases presented here.

The percentages given in Table 1 are for plant additions at an existing site, not for a new plant at an undeveloped site. They are based upon average values for typical plants, modified on the basis of information gathered in this study. For example, a manufacturer estimated installation costs at 30 percent of equipment costs. This figure was entered in Table 1 and used in the analysis.

\section{Table 1}

Ratio factors for estimating capital investment based on delivered equipment cost.

\begin{tabular}{lc}
\hline \multicolumn{1}{c}{ Item } & $\begin{array}{c}\text { Percent of } \\
\text { equipment cost }\end{array}$ \\
\hline Purchased equipment & 100 \\
Installation & 30 \\
Piping (installed) & 31 \\
Electrical (installed) & 10 \\
Buildings (including services) & 15 \\
Engineering and supervision & 24 \\
Contingency & 21 \\
\cline { 2 - 2 } Fixed capital investment & 231 \\
\hline
\end{tabular}

\section{Constructing the Cash Flow Table}

Methods of computation, prices, costs, escalation rates, and assumptions made in the analyses are presented in this section. A standard set of economic variables was used in making projections. Assumptions regarding realistic changes in these variables also were explained. These changes in an element of the problem were made to determine the sensitivity of the outcome to uncertainties regarding the value of a particular element. If a small change in the estimate of one element will alter the decision, the decision is said to be very sensitive to changes in the estimates of that element.

The discounted cash flow analyses required the construction of a cash flow table showing an array of returns and costs with a 20-year planning horizon covering the following variables: revenues (electricity savings), expenses (incremental fuel costs and other incremental operating and maintenance costs), depreciation, interest, taxes paid, net after tax profit, and cash flow. 
Revenues and expenses were determined for the base year (1985) in a manner soon to be described. These variables were multiplied by nominal escalation rates to obtain the estimated returns or costs for the year the cash flows occur. Unadjusted escalation rates were in real terms based upon 1980 dollars. Then, since income taxes are assessed in current dollars, and interest and loan payments are also in current dollars, the analysis was based on a nominal rate of escalation. The inflation rate was assumed to be 4 percent per year. The nominal rate equals the inflation rate plus the real rate, plus the inflation rate times the real rate.

The cash flows analyzed in this study are incremental revenues and expenses. For the actual cases, the base case consisted of the existing boiler and all equipment needed to produce sufficient steam to heat the dry kiln(s) required to season the sawmill's output of high quality lumber (\#1 common and better). The cogenerating system for the actual cases consisted of the existing boiler, a generator, major electrical equipment, and all other equipment and accessories needed to operate the generator and heat the dry kilns. The incremental investment was the value of the generator and associated equipment needed to convert the base case to a cogenerating facility.

The base case boiler size for the hypothetical cases was determined by the requirement for steam for kiln drying, whereas boiler size for the cogenerating system depended upon the requirement for steam for kiln drying and generating electricity. Thus, a somewhat larger boiler was required for the cogenerating system than for the base case. The incremental investment was the value of the extra boiler capacity, the generator, and associated equipment needed to transform the base case to a cogenerating facility. Therefore there is a small difference in the economic analysis of the actual cases compared to the hypothetical ones.

\section{Electricity savings (actual firms)}

Firm A cogenerated less electricity than it used during hours of plant operation. The sawmill operated two shifts of seven and one-half hours each for five days per week. It purchased electricity to make up the deficit. Electricity savings through cogeneration were calculated by estimating the kwh provided annually by Firm A during hours of sawmill operation and multiplying by $\$ .073$, the electricity rate. The kwh cogenerated annually at night and on weekends were estimated and multiplied by $\$ .023$, the off peak avoided cost rate at which the utility purchased electricity. The total revenue earned through cogeneration was the sum of annual savings realized during plant operation and the annual value of excess electricity sold during off hours. Firm A earned somewhat more revenue from cogeneration by operating on two shifts.

Firm B cogenerated sufficient electricity to meet its needs during hours of sawmill operation. Annual use of electricity if purchased was estimated in kwh 
from electrical bills for the year preceding installation of the cogenerating system. This was multiplied by $\$ .08$, the electricity rate, to estimate savings attributable to cogeneration. The excess kwh cogenerated annually on peak were estimated by subtracting annual inplant use from estimated annual on peak cogeneration. This excess was multiplied by $\$ .055$, the avoided cost, to estimate sales revenues on peak. Estimated annual off peak cogeneration in kwh was multiplied by $\$ .025$, the off peak avoided cost, to calculate the remaining sales revenue. Off peak cogeneration was limited owing to the relatively low off peak rate. The sum of the savings on electricity, realized during plant operations, and the value of the excess sold was equal to total revenue.

Firm $\mathrm{C}$ had the capacity to cogenerate all of its own electricity and to produce an excess for sale. It did neither. Firm $\mathrm{Chad}$ a contract with its utility to provide it with electricity in case of a breakdown in the cogenerating system. Under terms of this contract, it was obligated to purchase a minimum amount of energy. Revenues attributed to cogeneration were calculated as follows. Annual use in kwh was estimated from electricity bills of previous years. From this, the $k w h$ purchased were subtracted. The remaining kwh were multiplied by $\$ .065$, the electricity rate, to arrive at an estimate of savings. The cogenerating system of Firm $\mathrm{C}$ was not interconnected to the utility, so no purchase price had been established and no sales of electricity made.

\section{Electricity savings (hypothetical firms)}

For the hypothetical examples, an equation relating electricity use to sawmill size was used to estimate electricity cost if purchased. This equation was developed from data collected on electricity use from 37 West Virginia sawmills in 1984-85 (Patterson and Brock 1986). The equation, which was used to estimate monthly use for the four size classes previously defined, is as follows:

$$
\mathrm{Y}=4760+2750 \mathrm{X}+775 \mathrm{X}^{2}
$$

where: $\mathrm{Y}$ is the monthly electricity usage ( $\mathrm{kwh}$ ) and $\mathrm{X}$ is the mill size ( $\mathrm{mmbf}$ ).

The annual electricity cost was computed by multiplying the monthly usage given above by 12 , and then by $\$ 0.07$. The latter figure was deemed appropriate for use here based on information on electric rates gleaned from the sawmill survey (Patterson and Brock 1986).

Avoided costs are the savings a utility realizes from not having to generate the power itself or purchase it from the grid. Under the Public Utility Regulatory Policies Act of 1978 (PURPA), the rate paid to the cogenerator for purchased power may not exceed the avoided cost. The assumed $\$ 0.035$ per kwh avoided cost used in this study was provided by a utility operating in West Virginia. In sensitivity analysis, the avoided cost was reduced to $\$ 0.0175$ per kwh to determine the effect on NPV.

Each of the four sawmill size classes making up the hypothetical examples was provided with a generator of sufficient size to make it self-sufficient in 
electricity. The total amount of electricity generated per year for each example was next estimated. From this, the annual inplant use was subtracted to determine the excess. The surplus, in $\mathrm{kwh}$, was multiplied by $\$ 0.035$, the avoided cost. This was a 24-hour-a-day figure-there was no on peak or off peak. Sales revenues were added to the annual electricity cost if purchased to obtain the incremental electricity savings (revenue).

Electricity savings or revenues were projected to increase at a real annual rate of 1 percent from 1985 through the 20 -year period of analysis. This is a very conservative rate of increase. With an assumed annual rate of inflation of 4 percent, the nominal rate of escalation for this variable was 5.04 percent.

\section{Incremental fuel cost}

For the actual cases, the owner or manager was able to provide an estimate of fuel use in tons per hour with and without cogeneration. For the hypothetical examples, fuel use per hour was obtained from the equipment manufacturers. In these cases, sawdust and bark only were burned. Chips, being more valuable, were assumed to be sold to the pulp and paper industry or other users.

During cogeneration, it was assumed that wood residue would be fed into the boiler at rates approaching capacity. During periods when the generator was turned off, as under the ten hours of cogeneration per day assumption, lesser amounts of fuel would be used, and the boiler would be turned down. Annual fuel use during cogeneration was calculated by multiplying fuel use in tons per hour by number of cogenerating hours per year. Where cogeneration was intermittent, fuel use in tons per hour at turndown rates was determined and multiplied by annual hours operated at turndown. This latter estimate was added to fuel use during cogeneration to arrive at total fuel use. A similar approach was used to estimate total fuel use without cogeneration. Annual fuel costs were estimated by multiplying annual fuel use by the price of wood residue per ton.

For the actual cases, price information was supplied by the owner or manager. Firm A used a mixture of sawdust, bark, and chips with a price per ton at the sawmill of $\$ 5$ for the former fuels and $\$ 16$ for chips. The price of wood fuel per ton for Firm B was $\$ 6$, while at Firm $C$ wood residue had no value. Firm C could sell its sawdust for $\$ 6$ per ton delivered, but delivery costs amounted to about $\$ 6$ per ton. Thus, its opportunity cost for fuel was zero. Estimation of annual fuel costs without cogeneration (the base case) proceeded in a manner similar to that given for the cogenerating system described above. The difference in the two estimates, with and without cogeneration, was the annual incremental fuel cost.

Determining the average cost per ton of wood residue fuel for the hypothetical cases was somewhat complex. What is needed is the average cost of the additional fuel required to go from the base case to the cogenerating system. When cogenerating for 24 hours per day for 360 days per year, consumption of 
sawdust and bark for fuel exceeds production of residue. Consumption also exceeds production for the larger sawmills cogenerating ten hours per day for 250 days per year. It was assumed that this deficit could be made up through purchases from neighboring sawmills at a delivered price of $\$ 9$ per ton. The value of sawdust and bark at West Virginia sawmills was estimated to be no more than $\$ 2$ per ton as it is produced at the mill. Some sawmill operators in the state are disposing of wood residue in landfills. In such cases there is a cost, so the residue has a negative value.

To illustrate calculation of the average cost per ton of wood residue for the hypothetical cases, a sawmill producing 15 million board feet and cogenerating 24 hours per day was used as an example. Such a sawmill consumes an estimated 43,200 tons of residue per year, and produces an estimated 19,950 tons of sawdust and bark on the average per year (Patterson and Brock 1986). Residue consumption for the base case amounts to 8,640 tons per year. The price of residue is $\$ 2$ per ton for the difference between the 19,950 tons produced and 8,640 tons base case consumption. The cost to the sawmill on this part of the incremental fuel use is $\$ 2$ times 11,310 tons or $\$ 22,620$. The price of residue is $\$ 9$ per ton on the difference between the 43,200 tons cogenerating system consumption and the 19,950 tons of sawdust and bark production. The cost to the sawmill on this part of the incremental fuel use is $\$ 9$ times 23,250 tons or $\$ 209,250$. The incremental fuel cost is $\$ 231,870$ and incremental fuel use is 34,560 tons. So the average fuel cost is $\$ 6.71$ per ton. Average costs per ton for sawmills cogenerating 24 hours per day are lower for smaller mills because they purchase proportionately smaller amounts of the higher priced residue (Table 2). Sawmills producing 5 and 1 million board feet per year and cogenerating only ten hours per day produce more residue than they consume, so their costs are only $\$ 2$ per ton.

Incremental fuel costs were projected to increase at a real annual rate of 2 percent during the 20-year planning period ( $\mathrm{Lin} 1982$ ). With inflation at 4 percent, the nominal rate of escalation in fuel costs was 6.08 percent.

\section{Table 2}

Average cost per ton of incremental fuel used, by mill size and number of hours cogenerating per day.

\begin{tabular}{ccc}
\hline $\begin{array}{c}\text { Mill size } \\
\text { in mmbf }\end{array}$ & $\begin{array}{c}\text { Cogenerating } \\
\text { 24 hours/day }\end{array}$ & $\begin{array}{c}\text { Cogenerating } \\
\text { 10 hours/day }\end{array}$ \\
\hline 15 & $\$ 6.71$ & $\$ 3.58$ \\
10 & 6.02 & 2.15 \\
5 & 4.96 & 2.00 \\
1 & 4.15 & 2.00 \\
\hline
\end{tabular}




\section{Other incremental operating and maintenance costs}

Expenses included under this category were for the additional operating labor required for the cogenerating system as opposed to the base case, the additional maintenance labor and parts, the additional water including treatment costs, and the additional insurance. These costs were identified during the interviews conducted with owners or managers for the actual cases. Estimates of maintenance costs for the hypothetical examples were obtained from equipment manufacturers. Since the interviewees could not estimate the incremental property taxes, these taxes were not included in the actual case analyses. The taxes were estimated for the hypothetical cases, however, using information provided by Metz (1985).

Other incremental operating and maintenance costs were projected to increase at a real annual rate of 1 percent, or a nominal rate of 5.04 percent, over the 20-year planning period.

\section{Depreciation}

To reduce income tax liabilities an investment can be depreciated over several years. For this analysis, all depreciation was based upon the Accelerated Cost Recovery System (ACRS). Under this system, the equipment of a wood-fired cogenerating sawmill can be depreciated over five years according to the following schedule: first year at 15 percent; second year at 22 percent; third through fifth year at 21 percent. This schedule was used in all income tax computations.

In some cases, the revenue generated by the cogenerating system was insufficient to provide for writing off the full allowable depreciation under ACRS. In such cases, it was assumed that sufficient revenue was produced in other parts of the lumber manufacturing enterprise to provide the basis for writing off the full amount. This was credited to the cogenerating system.

\section{Interest}

Substantial investments in plant and equipment are necessary to initiate a cogenerating enterprise. Firm $A$ financed 80 percent of its required investment at an interest rate of 10 percent. Firm $B$ borrowed 75 percent of its requirements at an interest rate of 8 percent, while Firm C obtained 60 percent of its funds through financing at an interest rate of 10 percent. All three firms had a repayment period of ten years for these loans. A schedule of loan payments, including interest and principal, was computed for the actual cases and used in the cash flow analyses. Interest was a deduction when computing income taxes.

For the hypothetical cases, it was assumed that 60 percent of the required investment would be financed. The loans would be repaid in ten annual installments, with interest figured at 12 percent. 
Each owner or manager of the actual sawmills was queried to learn the rate he thought could be earned in his most favorable long-term alternative opportunity for investment. This inquiry resulted in alternative rates of return of 12 percent for Firm A, 10 percent for Firm B, and 10 percent for Firm C. These rates probably underestimate the risk inherent in the cogeneration enterprise. Nevertheless, they were used to discount cash flow for purposes of determining NPV. A discount rate of 15 percent was deemed appropriate for use with the hypothetical cases.

\section{Taxes paid}

At the time cash flow calculations were made, it was uncertain whether tax reform legislation then before Congress would contain provisions for investment or energy tax credits. It was decided to provide a basis for comparing the 1985 situation with the worst future situation envisioned, where no tax credits would be permitted. This was done in a straightforward manner with the actual cases: there were only two scenarios - with tax credits and with none. Only the actual electricity revenues were used. The hypothetical cases, however, were given an added feature: avoided costs were assumed to be at two levels, providing three scenarios. Under the most favorable set of assumptions, both tax credits were allowed while avoided costs were held at $\$ 0.035$ per kwh. Under an intermediate set of assumptions, neither tax credit was taken while avoided costs were held at the $\$ 0.035$ per kwh level. In the least favorable case, neither tax credit was taken while avoided costs were decreased to $\$ 0.0175$ per $\mathrm{kwh}$. Tax savings from the credits (if any) were treated as if they had occurred at year zero, the year immediately preceding startup. This treatment was deemed sufficient for this study (Grant et al. 1976).

For the actual cases, only federal income taxes were included in the analysis. No state taxes were taken. For the hypothetical examples, located in West Virginia, income taxes were calculated using a marginal federal rate of 46 percent and a marginal state rate of 7 percent. An effective tax rate was computed using the two marginal rates as follows:

Effective tax rate $=$

Federal rate ( 1 - state rate $)+$ state rate

Enterprises operating in West Virginia also have to pay a Business and Occupation (B\&O) Tax. For sales of electricity to electric utilities for subsequent resale to the ultimate consumer, the $\mathrm{B} \& \mathrm{O}$ tax rate is 4 percent of gross income received from the transaction. There is no $\mathrm{B} \& \mathrm{O}$ tax on the value of electricity generated but used to satisfy the plant's own needs.

\section{Net after tax profit}

This item is simply computed by subtracting taxes paid from taxable income. Taxable income is the difference between revenues and expenses, depreciation, and interest. 


\section{Cash flow}

Cash flow was computed by adding depreciation to net after tax profits and subtracting from this sum that component of the loan payment constituting principal. The depreciation is not a cash loss. The money which was subtracted as depreciation from revenues in determining taxable income was deducted for tax purposes and was added back to determine cash flow.

\section{Results}

\section{Actual Cases}

Firm A had an undersized generator compared to Firms C and B (Table 3). While Firm A's steam electric generator was purchased in used condition, the boiler was a 1984 model. It was large enough to provide sufficient steam for 11 dry kilns, and for operating the generator. Firm B had a highly capitalized cogenerating facility with all new equipment (Table 3). It operated no steamheated dry kilns, so the total capital investment in the cogeneration system may be viewed as the incremental investment. The base case did not exist. In this situation the analyst is asking if it pays to go from a zero base to the cogenerating system, rather than from the base case to the cogenerating system as in the other examples. Firm $\mathrm{C}$ utilized all used equipment for its cogenerating system which explains its relatively low total capital investment (Table 3). Its boilers had more than sufficient capacity to produce steam for its three dry kilns and generator.

\section{Table 3}

Capacity of generator, total capital investment, and incremental investment for the actual sawmill case studies, by firm.

\begin{tabular}{ccccc}
\hline & \multicolumn{3}{c}{ Total capital investment } \\
Actual & $\begin{array}{c}\text { Capacity of } \\
\text { generator } \\
\text { firm }\end{array}$ & $\begin{array}{c}\text { Cogenerating } \\
\text { system }\end{array}$ & $\begin{array}{c}\text { Base } \\
\text { case }\end{array}$ & $\begin{array}{c}\text { Incremental } \\
\text { investment }\end{array}$ \\
\hline A $(10 \mathrm{mmbf})$ & 540 & $\$ 1,339,800$ & $\$ 935,550$ & $\$ 404,250$ \\
B $(15 \mathrm{mmbf})$ & 1,325 & $2,113,650$ & -- & $2,113,650$ \\
C $(10 \mathrm{mmbf})$ & 1,000 & 358,050 & 173,250 & 184,800 \\
\hline
\end{tabular}

The loan amount plus tax credits (where applicable) minus the incremental investment was the cash outflow in year zero used in calculating the NPV. Selected cash flow tables for these computations are presented in the Appendix to illustrate the form and content of the data printout. Only investment tax credits were taken for Firms A and C since energy tax credits were not allowed for generators and related equipment (Table 4 ). The energy tax credit taken for 
Firm B excluded the generators. For Firm A, the NPV was positive with a discount rate of 12 percent, under both assumptions concerning availability of tax credits. The NPV for Firm B was positive when both tax credits were taken and negative when no tax credits were permitted, a discount rate of 10 percent being employed in the calculations. The NPV for Firm C was positive under both tax credit assumptions, with a discount rate of 10 percent (Table 4 ).

\section{Table 4}

Net present values for the actual sawmill case studies by firm and assumptions concerning tax credits.

\begin{tabular}{ccc}
\hline & \multicolumn{2}{c}{ Net present value } \\
Actual & Tax & No tax \\
firm & credits & credits \\
\hline A $(10 \mathrm{mmbf})$ & $\$ 621,878^{\star}$ & $\$ 588,904$ \\
B $(15 \mathrm{mmbf})$ & 185,210 & $-111,308$ \\
C $(10 \mathrm{mmbf})$ & $182,024^{\star}$ & 167,559 \\
\hline
\end{tabular}

*Only investment tax credit taken.

\section{Hypothetical Cases}

The capacity of the generator for each sawmill size class included in the hypothetical case studies is given in Table 5 . As can be seen from other data presented, a considerable investment ranging from $\$ 2,017,785$ for the largest sawmill size class to $\$ 643,681$ for the smallest is required for the complete cogenerating system (Table 5).

\section{Table 5}

Capacity of generator, total capital investment and incremental investment for the hypothetical sawmill case studies, by mill size.

\section{Total capital investment}

\begin{tabular}{|c|c|c|c|c|}
\hline $\begin{array}{l}\text { Mill size } \\
\text { in } \mathrm{mmbf}\end{array}$ & $\begin{array}{l}\text { Capacity of } \\
\text { generator } \\
\text { in kw }\end{array}$ & $\begin{array}{l}\text { Cogenerating } \\
\text { system }\end{array}$ & $\begin{array}{l}\text { Base } \\
\text { case }\end{array}$ & $\begin{array}{l}\text { Incremental } \\
\text { investment }\end{array}$ \\
\hline 15 & 1,350 & $\$ 2,017,785$ & $\$ 1,212,750$ & $\$ 805,035$ \\
\hline 10 & 700 & $1,665,510$ & $1,062,600$ & 602,910 \\
\hline 5 & 250 & $1,119,195$ & 785,400 & 333,795 \\
\hline 1 & 65 & 643,681 & 519,750 & 123,931 \\
\hline
\end{tabular}


The investment made for the base case involves a somewhat smaller boiler than is needed for the cogenerating system. The loan amount plus tax credits when taken, minus the incremental investment, was the cash outflow at the beginning of the investment period for each cash flow analysis. Selected cash flow tables are given in the Appendix. No energy tax credit was taken on the capital value represented by the generator.

The first hypothetical cases considered were those sawmills cogenerating 24 hours per day for 360 days per year (Table 6). All calculations of NPV were carried out with a discount rate of 15 percent. Assuming both tax credits could be taken and avoided costs were $\$ 0.035$ per kwh, the NPV was positive for each sawmill size class considered except the smallest. The situation changed when no tax credits were allowed, however. Only the 15 and 10 million board feet size classes were economical under this assumption although avoided costs were held at the $\$ 0.035$ per kwh level. When no tax credits could be taken and avoided costs were reduced to $\$ 0.0175$ per $k w h$, the worst scenario, each size class had a negative NPV (Table 6).

\section{Table 6}

Net present value for sawmills cogenerating 24 hours per day for 360 days per year, according to mill size and assumptions concerning tax credits and avoided costs.

\begin{tabular}{|c|c|c|c|}
\hline \multirow[b]{2}{*}{$\begin{array}{l}\text { Mill size } \\
\text { in mmbf }\end{array}$} & \multicolumn{3}{|c|}{ Net present value } \\
\hline & $\begin{array}{c}\text { Tax credits } \\
\text { with avoided } \\
\text { costs at } \$ 0.035\end{array}$ & $\begin{array}{l}\text { No tax credits } \\
\text { with avoided } \\
\text { costs at } \$ 0.035\end{array}$ & $\begin{array}{l}\text { No tax credits } \\
\text { with avoided } \\
\text { costs at } \$ 0.0175\end{array}$ \\
\hline 15 & $\$ 318,886$ & $\$ 212,004$ & $\$-268,698$ \\
\hline 10 & 95,700 & 18,419 & $-261,931$ \\
\hline 5 & 8,599 & $-34,636$ & $-135,832$ \\
\hline 1 & $-2,327$ & $-17,626$ & $-43,158$ \\
\hline
\end{tabular}

The second set of hypothetical cases were sawmills cogenerating 10 hours per day for 250 days per year (Table 7). A discount rate of 15 percent was again employed in all NPV calculations. When tax credits were taken and avoided costs were at their highest assumed level of $\$ 0.035$ per $\mathrm{kwh}$, only the two largest size class sawmills provided economic opportunities for investment (Table 7). When no tax credits were allowed, but with avoided costs at the $\$ 0.035$ per kwh level, only the 15 million board feet size class had a positive NPV. This size class remained the only viable investment opportunity under the worst scenario (Table 7). All other size classes were uneconomic when avoided costs were reduced to $\$ 0.0175$ per $\mathrm{kwh}$. 


\section{Table 7}

Net present values for sawmills cogenerating 10 hours per day for 250 days per year, according to mill size and assumptions concerning tax credits and avoided costs.

\begin{tabular}{cccc}
\hline \hline & \multicolumn{3}{c}{ Net present value } \\
\cline { 2 - 4 } Mill size & $\begin{array}{c}\text { Tax credits } \\
\text { with avoided }\end{array}$ & $\begin{array}{c}\text { No tax credits } \\
\text { with avoided }\end{array}$ & $\begin{array}{c}\text { No tax credits } \\
\text { with avoided } \\
\text { in mmbf }\end{array}$ \\
costs at $\$ 0.035$ & costs at $\$ 0.035$ & costs at $\$ 0.0175$ \\
\hline 15 & $\$ 212,010$ & $\$ 105,128$ & $\$ 93,748$ \\
10 & 65,264 & $-12,016$ & $-29,546$ \\
5 & $-20,323$ & $-63,558$ & $-70,889$ \\
1 & $-26,288$ & $-41,586$ & $-44,173$ \\
\hline
\end{tabular}

The NPV remained positive for the 15 million board feet size class even when avoided costs were reduced to their lowest assumed level because only a small percentage of the electricity generated was sold to a utility. Most of it was used in the plant and imputed a value of $\$ 0.07$ per $\mathrm{kwh}$. It should be noted that a sawmill producing 15 million board feet of lumber annually and cogenerating 24 hours per day has a negative NPV under the worst assumptions concerning tax credits and avoided costs in Table 6 . The main reason for the change in sign for the same entry in Table 7 is the much lower fuel cost per ton ( $\$ 3.58$ vs. $\$ 6.71)$.

\section{Conclusion}

The main objectives of this research were to construct a model and computer program for evaluating investment opportunities in cogeneration at sawmills, and to use this information to compute decision criteria for some actual and hypothetical case studies applicable to West Virginia. The interactive computer program and user's guide developed for this project will be provided upon request.

Under the assumptions made herein for the hypothetical cases, incremental costs of wood residue were as low as $\$ 2.00$ per ton at the smallest sawmills studied (Table 2). However, only under the most favorable circumstances was it economical to use wood residue as fuel at such sawmills despite its low cost. Larger producers, on the other hand, sometimes were able to use higher cost fuel economically.

Total capital investment for equipping a cogenerating system requires a sizeable cash outlay. Even an entirely used system may exceed $\$ 350,000$ in cost. This, of course, does not include expenditures for dry kilns. Investment for a new system may exceed $\$ 2,000,000$ (Tables 3 and 5). 
Firms $\mathrm{A}$ and $\mathrm{C}$ produced acceptable economic returns. When tax credits were available, Firm $B$ also produced an attractive return. However, when no tax credits were allowed, the NPV for Firm B's investment was negative. Firm $\mathrm{B}$, of course, operated no steam-heated dry kilns. The full burden of producing revenue fell upon the electric generator. This sawmill was not actually cogenerating and the owner was wasting resources. Nevertheless, it seems safe to conclude that investment and energy tax credits encouraged investment in cogeneration at sawmills. Without them some opportunities for investment may be lost.

Firm $\mathrm{C}$ was involved in a dispute with its utility over which party would pay the cost of equipment needed to interconnect. As a result, it was unable to sell any electricity. This cost Firm $C$ an estimated $\$ 100,000$ per year in lost revenue.

The hypothetical cases yielded some interesting results. For sawmills cogenerating 24 hours per day, under the most favorable circumstances all mill size classes except the very smallest provided economic investments. However, it seems doubtful that even 5 million board feet producers would provide sufficiently reliable supplies of electricity to command a $\$ 0.035$ per kwh avoided cost rate. More likely, these small manufacturers would receive only half as much, being casual power producers, making investment in cogeneration unattractive for them.

The availability of tax credits had a moderate influence on results. The NPV for sawmills producing 5 million board feet changed sign to negative with no tax credits. The results also were sensitive to decreases in electricity revenue. All size class mills were uneconomic when avoided costs were reduced by one-half.

Cogenerating for only 10 hours per day mainly to meet the plant's own needs does not appear to be as productive as cogenerating for longer periods and selling the excess electricity. This is true even with the relatively low avoided cost rates assumed here. This study did not seek an optimum schedule for cogeneration. Such is the topic for future research.

The results of this study indicate that investment in cogeneration is decidedly more attractive to the larger sawmills, those producing 10 million board feet and more. And it is these sawmills with their greater resources which often are in a better position to obtain financing for the sizeable investment required. Indeed, availability of financing is an important factor in encouraging investment in cogeneration.

Sawmills producing 15 million board feet of lumber annually would probably find it profitable to invest in a cogeneration enterprise in West Virginia even without investment and energy tax credits. Relatively low avoided cost rates mitigate against such investments, however, and may be an important reason why no sawmills cogenerate in West Virginia at present. 
Other reasons include the large investment required and lack of familiarity with the technology. The prospect and uncertainty of negotiations with a utility over interconnection and avoided cost rates may also impede investment.

In 1985, there were only a handful of cogenerating sawmills in operation in the entire Southeastern region. In the neighboring states of Pennsylvania, Virginia, and Kentucky there were but three sawmills suitable for this research. These were all moderately large to large operations, which is in accord with the findings of this research that investment in cogeneration at small sawmills is generally not economical. Indeed, there appear to be considerable economies to scale associated with cogeneration at sawmills. Use of wood residue for fueling boilers for purposes of cogeneration at sawmills is still in the experimental stage. Experience gained at the large production units now in operation will help determine the future prospects for cogeneration at sawmills. 


\section{Literature Cited}

Duerr, W.A. 1960. Fundamentals of forestry economics. McGraw-Hill Book Company, New York. 579 pp.

Fields, T.D. and W.A. Duncan. 1981. Kiln drying hardwoods in East Kentucky: A feasibility and design analysis. Mountain Association for Community Economic Development (MACED). Berea, Kentucky. 78 pp.

Grant, E.L., W.G. Ireson, and R.S. Leavenworth. 1976. Principles of engineering economy. Sixth edition. John Wiley and Sons, New York. 624 pp.

Lin, F.B. 1982. Wood-fired steam production at Clarkson College of Technology. New York State Energy Research and Development Authority. Albany, New York. Chap. 5.

Metz, M.A. 1985. "Concentration-dry kiln enterprise in Nicholas County, West Virginia: A feasibility study." MSF thesis, West Virginia Univ., Morgantown. $86 \mathrm{pp}$.

Patterson, D.W. and S.M. Brock. 1986. "Electricity usage and residues production at West Virginia sawmills." West Virginia Forestry Notes. No. 12.

Peters, M.S. and K. D. Timmerhaus. 1980. Plant design and economics for chemical engineers. Third edition. McGraw-Hill Book Company, New York. $973 \mathrm{pp}$.

Walton, D.R. 1985. "Economic evaluation of a residue system for kiln drying hardwood lumber in West Virginia." MSF thesis, West Virginia Univ., Morgantown. $146 \mathrm{pp}$. 


\section{Appendix}

Cash Flow Tables for Selected Cases 


\section{Appendix Table 1}

Estimating cash flow for Firm A, a 10 mmbf sawmill cogenerating 24 hours per day for 360 days per year. (Only investment tax credit taken.)

\begin{tabular}{cccr}
\hline \multicolumn{4}{c}{ Summary of Loan Repayment } \\
\hline Year & Interest & Principal & Balance \\
\hline 1 & 32340 & 20292 & 303108 \\
2 & 30311 & 22321 & 280787 \\
3 & 28079 & 24553 & 256234 \\
4 & 25623 & 27008 & 229225 \\
5 & 22923 & 29709 & 199516 \\
6 & 19952 & 32680 & 166836 \\
7 & 16684 & 35948 & 130888 \\
8 & 13089 & 39543 & 91344 \\
9 & 9134 & 43497 & 47847 \\
10 & 4785 & 47847 & 0 \\
\hline
\end{tabular}


Cash Flow Table

\begin{tabular}{rrrrrrrrrr}
\hline \hline Yr & $\begin{array}{c}\text { Capital } \\
\text { costs }\end{array}$ & $\begin{array}{c}\text { Depreci- } \\
\text { ation }\end{array}$ & $\begin{array}{c}\text { Fuel } \\
\text { costs }\end{array}$ & Revenue & $\begin{array}{r}\text { O\&M } \\
\text { costs }\end{array}$ & $\begin{array}{c}\text { Taxable } \\
\text { income }\end{array}$ & Taxes & NATP & $\begin{array}{c}\text { Cash } \\
\text { flow }\end{array}$ \\
\hline 0 & 404250 & 0 & 0 & 0 & 0 & 0 & 0 & 0 & -41425 \\
1 & 0 & 56181 & 4590 & 200740 & 12412 & 53817 & 24756 & 29061 & 64950 \\
2 & 0 & 82398 & 48786 & 210857 & 13038 & 36324 & 16709 & 19615 & 79692 \\
3 & 0 & 78653 & 51752 & 221485 & 13695 & 49306 & 22681 & 26625 & 80725 \\
4 & 0 & 78653 & 54899 & 232647 & 14385 & 59087 & 27180 & 31907 & 83552 \\
5 & 0 & 78653 & 58237 & 244373 & 15110 & 69451 & 31947 & 37503 & 86447 \\
6 & 0 & 0 & 61778 & 256689 & 15871 & 159089 & 73181 & 85908 & 53228 \\
$\sim$ & 0 & 0 & 65534 & 269626 & 16671 & 170738 & 78539 & 92198 & 56250 \\
7 & 0 & 0 & 69518 & 283215 & 17512 & 183097 & 84225 & 98872 & 59329 \\
8 & 0 & 0 & 73745 & 297489 & 18394 & 196216 & 90259 & 105957 & 62459 \\
9 & 0 & 0 & 78228 & 312483 & 19321 & 210149 & 96668 & 113480 & 65633 \\
10 & 0 & 0 & 82985 & 328232 & 20295 & 224952 & 103478 & 121474 & 121474 \\
11 & 0 & 0 & 88030 & 344775 & 21318 & 235427 & 108296 & 127131 & 127131 \\
12 & 0 & 0 & 93383 & 362152 & 22392 & 246377 & 113333 & 133044 & 133044 \\
13 & 0 & 0 & 99060 & 380404 & 23521 & 257823 & 118599 & 139224 & 139224 \\
14 & 0 & 0 & 105083 & 399576 & 24706 & 269787 & 124102 & 145685 & 145685 \\
15 & 0 & 0 & 111472 & 419715 & 25951 & 282292 & 129854 & 152437 & 152437 \\
16 & 0 & 0 & 118250 & 440869 & 27259 & 295360 & 135865 & 159494 & 159494 \\
17 & 0 & 0 & 125439 & 463089 & 28633 & 309016 & 142147 & 166869 & 166869 \\
18 & 0 & 0 & 133066 & 486428 & 30076 & 323286 & 148712 & 174574 & 174574 \\
19 & 0 & 0 & 141156 & 510944 & 31592 & 338196 & 155570 & 182626 & 182626 \\
20 & 0 & & & & & & & &
\end{tabular}




\section{Appendix Table 2}

Estimating cash flow for Firm A, a 10 mmbf sawmill cogenerating 24 hours per day for 360 days per year. (No tax credits taken.)

\begin{tabular}{cccr}
\hline \multicolumn{4}{c}{ Summary of Loan Repayment } \\
\hline Year & Interest & Principal & Balance \\
\hline 1 & 32340 & 20292 & 303108 \\
2 & 30311 & 22321 & 280787 \\
3 & 28079 & 24553 & 256234 \\
4 & 25623 & 27008 & 229225 \\
5 & 22923 & 29709 & 199516 \\
6 & 19952 & 32680 & 166836 \\
7 & 16684 & 35948 & 130888 \\
8 & 13089 & 39543 & 91344 \\
9 & 9134 & 43497 & 47847 \\
10 & 4785 & 47847 & 0 \\
\hline
\end{tabular}


Cash Flow Table

\begin{tabular}{|c|c|c|c|c|c|c|c|c|c|}
\hline $\mathbf{Y r}$ & $\begin{array}{c}\text { Capital } \\
\text { costs }\end{array}$ & $\begin{array}{c}\text { Depreci- } \\
\text { ation }\end{array}$ & $\begin{array}{l}\text { Fuel } \\
\text { costs }\end{array}$ & Revenue & $\begin{array}{l}\text { O\&M } \\
\text { costs }\end{array}$ & $\begin{array}{l}\text { Taxable } \\
\text { income }\end{array}$ & Taxes & NATP & $\begin{array}{l}\text { Cash } \\
\text { flow }\end{array}$ \\
\hline 0 & 404250 & 0 & 0 & 0 & 0 & 0 & 0 & 0 & -80850 \\
\hline 1 & 0 & 59138 & 45990 & 200740 & 12412 & 50860 & 23396 & 27465 & 66310 \\
\hline 2 & 0 & 86735 & 48676 & 210857 & 13038 & 31988 & 14714 & 17273 & 81687 \\
\hline 3 & 0 & 82792 & 51752 & 221485 & 13695 & 45166 & 20776 & 24390 & 82629 \\
\hline 4 & 0 & 82792 & 54899 & 232647 & 14385 & 54948 & 25276 & 29672 & 85456 \\
\hline 5 & 0 & 82792 & 58237 & 244373 & 15110 & 65311 & 30043 & 35268 & 88351 \\
\hline 6 & 0 & 0 & 61778 & 256689 & 15871 & 159089 & 73181 & 85908 & 53228 \\
\hline 7 & 0 & 0 & 65534 & 269626 & 16671 & 170738 & 78539 & 92198 & 56250 \\
\hline 8 & 0 & 0 & 69518 & 283215 & 17512 & 183097 & 84225 & 98872 & 59329 \\
\hline 9 & 0 & 0 & 73745 & 297489 & 18394 & 196216 & 90259 & 105957 & 62459 \\
\hline 10 & 0 & 0 & 78228 & 312483 & 19321 & 210149 & 96668 & 113480 & 65633 \\
\hline 11 & 0 & 0 & 82985 & 328232 & 20295 & 224952 & 103478 & 121474 & 121474 \\
\hline 12 & 0 & 0 & 88030 & 344775 & 21318 & 235427 & 108296 & 127131 & 127131 \\
\hline 13 & 0 & 0 & 93383 & 362152 & 22392 & 346377 & 113333 & 133044 & 133044 \\
\hline 14 & 0 & 0 & 99060 & 380404 & 23521 & 257823 & 118599 & 139224 & 139224 \\
\hline 15 & 0 & 0 & 105083 & 399576 & 24706 & 269787 & 124102 & 145685 & 145685 \\
\hline 16 & 0 & 0 & 111472 & 419715 & 25951 & 282292 & 129854 & 152437 & 152437 \\
\hline 17 & 0 & 0 & 118250 & 440869 & 27259 & 295360 & 135865 & 159494 & 159494 \\
\hline 18 & 0 & 0 & 125439 & 463089 & 28633 & 309016 & 142147 & 166869 & 166869 \\
\hline 19 & 0 & 0 & 133066 & 486428 & 30076 & 323286 & 148712 & 174574 & 174574 \\
\hline 20 & 0 & 0 & 141156 & 510944 & 31592 & 338196 & 155570 & 182626 & 182626 \\
\hline
\end{tabular}




\section{Appendix Table 3}

Estimating cash flow for a $15 \mathrm{mmbf}$ sawmill cogenerating 24 hours per day for 360 days per year. (Both tax credits taken with avoided costs at $\$ 0.035$ per kwh.)

\section{Summary of Loan Repayment}

\begin{tabular}{cccc}
\hline Year & Interest & Principal & Balance \\
\hline 1 & 57963 & 27525 & 455496 \\
2 & 54660 & 30828 & 424669 \\
3 & 50960 & 34527 & 390142 \\
4 & 46817 & 38670 & 351472 \\
5 & 42177 & 43310 & 308161 \\
6 & 36979 & 48508 & 259654 \\
7 & 31158 & 54329 & 205325 \\
8 & 24639 & 60848 & 144477 \\
9 & 17337 & 68150 & 76327 \\
10 & 9159 & 76328 & 0 \\
\hline
\end{tabular}


Cash Flow Table

\begin{tabular}{|c|c|c|c|c|c|c|c|c|c|}
\hline $\mathbf{Y r}$ & $\begin{array}{c}\text { Capital } \\
\text { costs }\end{array}$ & $\begin{array}{c}\text { Depreci- } \\
\text { ation }\end{array}$ & $\begin{array}{l}\text { Fuel } \\
\text { costs }\end{array}$ & Revenue & $\begin{array}{l}\text { O\&M } \\
\text { costs }\end{array}$ & $\begin{array}{l}\text { Taxable } \\
\text { income }\end{array}$ & Taxes & NATP & $\begin{array}{l}\text { Cash } \\
\text { flow }\end{array}$ \\
\hline 0 & 805035 & 0 & 0 & 0 & 0 & 0 & 0 & 0 & -202085 \\
\hline 1 & 0 & 113292 & 231898 & 432775 & 24172 & 5451 & 12618 & -7168 & 78600 \\
\hline 2 & 0 & 166162 & 245997 & 454587 & 25390 & -37622 & -8324 & -29298 & 106037 \\
\hline 3 & 0 & 158609 & 260954 & 477498 & 26670 & -19695 & 1124 & -20819 & 103263 \\
\hline 4 & 0 & 158609 & 276820 & 501564 & 28014 & -8696 & 7150 & -15847 & 104093 \\
\hline 5 & 0 & 158609 & 293650 & 526843 & 29426 & 2981 & 13542 & -10561 & 104738 \\
\hline 6 & 0 & 0 & 311504 & 553396 & 30909 & 174003 & 99284 & 74719 & 26211 \\
\hline 7 & 0 & 0 & 330444 & 581287 & 32467 & 187218 & 106501 & 80717 & 26388 \\
\hline 8 & 0 & 0 & 350535 & 610584 & 34103 & 201307 & 114185 & 87122 & 26274 \\
\hline 9 & 0 & 0 & 371847 & 641357 & 35822 & 216351 & 122378 & 93973 & 25823 \\
\hline 10 & 0 & 0 & 394455 & 673682 & 37627 & 232440 & 131127 & 101313 & 24985 \\
\hline 11 & 0 & 0 & 418438 & 707635 & 39524 & 249673 & 140483 & 109190 & 109190 \\
\hline 12 & 0 & 0 & 443879 & 743300 & 41516 & 257905 & 145397 & 112508 & 112508 \\
\hline 13 & 0 & 0 & 470867 & 780762 & 43608 & 266287 & 150427 & 115860 & 115860 \\
\hline 14 & 0 & 0 & 499496 & 820113 & 45806 & 274811 & 155571 & 119240 & 119240 \\
\hline 15 & 0 & 0 & 529865 & 861446 & 48115 & 283466 & 160826 & 122641 & 122641 \\
\hline 16 & 0 & 0 & 562081 & 904863 & 50540 & 292243 & 166188 & 126054 & 126054 \\
\hline 17 & 0 & 0 & 596256 & 950468 & 53087 & 301126 & 171654 & 129472 & 129472 \\
\hline 18 & 0 & 0 & 632508 & 998372 & 55763 & 310102 & 177218 & 132883 & 132883 \\
\hline 19 & 0 & 0 & 670964 & 1048690 & 58573 & 319153 & 182876 & 136277 & 136277 \\
\hline 20 & 0 & 0 & 711759 & 1101544 & 61525 & 328260 & 188619 & 139641 & 139641 \\
\hline
\end{tabular}




\section{Appendix Table 4}

Estimating cash flow for a $15 \mathrm{mmbf}$ sawmill cogenerating 24 hours per day for 360 days per year. (No tax credits taken with avoided costs at $\$ 0.035$ per kwh.)

\begin{tabular}{cccr}
\hline \multicolumn{4}{c}{ Summary of Loan Repayment } \\
\hline Year & Interest & Principal & Balance \\
\hline 1 & 57963 & 27525 & 455496 \\
2 & 54660 & 30828 & 424669 \\
3 & 50960 & 34527 & 390142 \\
4 & 46817 & 38670 & 351472 \\
5 & 42177 & 43310 & 308161 \\
6 & 36979 & 48508 & 259654 \\
7 & 31158 & 54329 & 205325 \\
8 & 24639 & 60848 & 144477 \\
9 & 17337 & 68150 & 76327 \\
10 & 9159 & 76328 & 0 \\
\hline
\end{tabular}


Cash Flow Table

\begin{tabular}{rrrrrrrrrr}
\hline \hline Yr & $\begin{array}{c}\text { Capital } \\
\text { costs }\end{array}$ & $\begin{array}{c}\text { Depreci- } \\
\text { ation }\end{array}$ & $\begin{array}{c}\text { Fuel } \\
\text { costs }\end{array}$ & Revenue & $\begin{array}{c}\text { O\&M } \\
\text { costs }\end{array}$ & $\begin{array}{r}\text { Taxable } \\
\text { income }\end{array}$ & Taxes & NATP & $\begin{array}{r}\text { Cash } \\
\text { flow }\end{array}$ \\
\hline 0 & 805035 & 0 & 0 & 0 & 0 & 0 & 0 & 0 & -322014 \\
1 & 0 & 231898 & 231989 & 432775 & 24172 & -512 & 9650 & -10162 & 81568 \\
2 & 0 & 174908 & 245997 & 454587 & 25390 & -46368 & -12678 & -33690 & 110390 \\
3 & 0 & 166957 & 260954 & 477498 & 26670 & -28043 & -3031 & -25012 & 107419 \\
4 & 0 & 166957 & 276820 & 501564 & 28014 & -17044 & 2995 & -20039 & 108248 \\
5 & 0 & 166957 & 293650 & 526843 & 29426 & -5637 & 9386 & -14753 & 108893 \\
6 & 0 & 0 & 311504 & 553396 & 30909 & 174003 & 99284 & 74719 & 26211 \\
7 & 0 & 0 & 330444 & 581287 & 32467 & 187218 & 106501 & 80717 & 26388 \\
\multirow{3}{*}{} & 0 & 0 & 350535 & 610584 & 34103 & 201307 & 114185 & 87122 & 26274 \\
9 & 0 & 0 & 371847 & 641357 & 35822 & 216351 & 122378 & 93973 & 25823 \\
10 & 0 & 0 & 394455 & 673682 & 37627 & 232440 & 131127 & 101313 & 24985 \\
11 & 0 & 0 & 418438 & 707635 & 39524 & 249673 & 140483 & 109190 & 109190 \\
12 & 0 & 0 & 443879 & 743300 & 41516 & 257905 & 145397 & 112508 & 112508 \\
13 & 0 & 0 & 470867 & 780762 & 43608 & 266287 & 150427 & 115860 & 115860 \\
14 & 0 & 0 & 499496 & 820113 & 45806 & 274811 & 155571 & 119240 & 119240 \\
15 & 0 & 0 & 529865 & 861446 & 48115 & 283466 & 160826 & 122641 & 122641 \\
16 & 0 & 0 & 562081 & 904863 & 50540 & 292243 & 166188 & 126054 & 126054 \\
17 & 0 & 0 & 596256 & 950468 & 53087 & 301126 & 171654 & 129472 & 129472 \\
18 & 0 & 0 & 632508 & 998372 & 55763 & 310102 & 177218 & 132883 & 132883 \\
19 & 0 & 0 & 670964 & 1048690 & 58573 & 319153 & 182876 & 136277 & 136277 \\
20 & 0 & 0 & 711759 & 1101544 & 61525 & 328260 & 188619 & 139641 & 139641 \\
\hline
\end{tabular}




\section{Appendix Table 5}

Estimating cash flow for a $15 \mathrm{mmbf}$ sawmill cogenerating 24 hours per day for 360 days per year. (No tax credits taken with avoided costs at $\$ 0.0175$ per kwh.)

\begin{tabular}{cccr}
\hline \multicolumn{4}{c}{ Summary of Loan Repayment } \\
\hline Year & Interest & Principal & Balance \\
\hline 1 & 57963 & 27525 & 455496 \\
2 & 54660 & 30828 & 424669 \\
3 & 50960 & 34527 & 390142 \\
4 & 46817 & 38670 & 351472 \\
5 & 42177 & 43310 & 308161 \\
6 & 36979 & 48508 & 259654 \\
7 & 31158 & 54329 & 205325 \\
8 & 24639 & 60848 & 144477 \\
9 & 17337 & 68150 & 76327 \\
10 & 9159 & 76328 & 0 \\
\hline
\end{tabular}


Cash Flow Table

\begin{tabular}{|c|c|c|c|c|c|c|c|c|c|}
\hline $\mathbf{Y r}$ & $\begin{array}{l}\text { Capital } \\
\text { costs }\end{array}$ & $\begin{array}{c}\text { Depreci- } \\
\text { ation }\end{array}$ & $\begin{array}{l}\text { Fuel } \\
\text { costs }\end{array}$ & Revenue & $\begin{array}{l}O \& M \\
\text { costs }\end{array}$ & $\begin{array}{l}\text { Taxable } \\
\text { income }\end{array}$ & Taxes & NATP & $\begin{array}{l}\text { Cash } \\
\text { flow }\end{array}$ \\
\hline 0 & 805035 & 0 & 0 & 0 & 0 & 0 & 0 & 0 & -322014 \\
\hline 1 & 0 & 119255 & 231898 & 308963 & 24172 & -124325 & -56936 & -67388 & 24342 \\
\hline 2 & 0 & 174908 & 245997 & 324534 & 25390 & -176420 & -82620 & -93800 & 50280 \\
\hline 3 & 0 & 166957 & 260954 & 340891 & 26670 & -164650 & -76499 & -88152 & 44279 \\
\hline 4 & 0 & 166957 & 276820 & 358072 & 28014 & -160536 & -74175 & -86361 & 41926 \\
\hline 5 & 0 & 166957 & 293650 & 376119 & 29426 & -156092 & -71673 & -84418 & 39229 \\
\hline 6 & 0 & 0 & 311504 & 395075 & 30909 & 15682 & 14140 & 1543 & -46965 \\
\hline 7 & 0 & 0 & 330444 & 414987 & 32467 & 20918 & 17065 & 3853 & -50476 \\
\hline 8 & 0 & 0 & 350535 & 435902 & 34103 & 26625 & 20241 & 6384 & -54464 \\
\hline 9 & 0 & 0 & 371847 & 457872 & 35822 & 32865 & 23700 & 9166 & -58984 \\
\hline 10 & 0 & 0 & 394455 & 480948 & 37627 & 39706 & 27475 & 12231 & -64097 \\
\hline 11 & 0 & 0 & 418438 & 505188 & 39524 & 47226 & 31607 & 15619 & 15619 \\
\hline 12 & 0 & 0 & 443879 & 530650 & 41516 & 45255 & 31034 & 14221 & 14221 \\
\hline 13 & 0 & 0 & 470867 & 557394 & 43608 & 42919 & 30300 & 12619 & 12619 \\
\hline 14 & 0 & 0 & 499496 & 585487 & 45806 & 40185 & 29389 & 10796 & 10796 \\
\hline 15 & 0 & 0 & 529865 & 614996 & 48115 & 37016 & 28284 & 8731 & 8731 \\
\hline 16 & 0 & 0 & 462081 & 645991 & 50540 & 33371 & 26967 & 6404 & 6404 \\
\hline 17 & 0 & 0 & 596256 & 678549 & 53087 & 29207 & 25416 & 3791 & 3791 \\
\hline 18 & 0 & 0 & 632508 & 712748 & 55763 & 24478 & 23610 & 868 & 868 \\
\hline 19 & 0 & 0 & 670964 & 748671 & 58573 & 19133 & 21525 & -2392 & -2392 \\
\hline 20 & 0 & 0 & 711759 & 786404 & 61525 & 13120 & 19137 & -6017 & -6017 \\
\hline
\end{tabular}




\section{[Blank Page in Original Bulletin]}


[Blank Page in Original Bulletin] 
